\title{
Research of Alkali Silica Reaction in Concrete With Active Mineral Additives
}

\author{
Audrius Grinys*, Vytautas Bocullo, Algirdas Gumuliauskas
}

Kaunas University of Technology, Faculty of Civil Engineering and Architecture, Studentu g. 48, LT-51367 Kaunas, Lithuania.

*Corresponding author: Audrius.Grinys@ktu.lt,

cross'ref http://dx.doi.org/10.5755/j01.sace.6.1.6354

This paper analyses the effect of mineral additives on alkali - silica reaction. Amorphous $\mathrm{SiO}_{2}$ contained in concrete aggregate is known for reactions with $\mathrm{Na}_{2} \mathrm{O}$ and $\mathrm{K}_{2} \mathrm{O}$ that cause concrete expansion and cracking. Concrete expansion is the result of silicates reaction (ASR). Alkali silica gel is a reaction product having expanding properties. Expanding silica gel creates stress that causes concrete cracking. The paper investigates the elimination of the negative effect of ASR by using fly ash as active mineral additive. In the tests active mineral additive (fly ash) is expected to reduce the effect of alkali - silica reaction and volumetric strain.

Keywords: Alkali - silica reaction, mineral additives, fly ash, hydrated silicates, concrete, bonding agent.

\section{Introduction}

ASR i.e. reaction of alkali and silica gel in granular matrix composites, is destruction caused by adverse chemical reactions between the alkali present in hardened concrete $\left(\mathrm{Na}_{2} \mathrm{O}\right.$ and $\left.\mathrm{K}_{2} \mathrm{O}\right)$ and reactive silica or carbonate components present in the aggregates (Gumuliauskas, Navickas, 2007). Such corrosion may even lead to structure failures; therefore it is very important to find ways to reduce it and produce alkali - silica reaction resistant concrete. This issue has been investigated for more than 70 years; numerous tests have been conducted and described in scientific papers.

During cement hardening $\mathrm{SiO}_{2}$ reacts with $\mathrm{Na}_{2} \mathrm{O}$ and $\mathrm{K}_{2} \mathrm{O}$ and hydrosilicate crystals of alkali metals with variable content of crystalized water are formed on the surface of reactive aggregates. Such corrosion of concrete becomes especially visible on the surface of concrete structures, where pieces of opal aggregates are pressed out from the surface layer (Balandis et al., 2006).

In this case concrete destruction is caused by alkalisilica reaction (ASR) in concrete mixture. Usually alkali silica reaction is an acid-base reaction between calcium hydroxide $\left(\mathrm{Ca}(\mathrm{OH})_{2}\right)$, otherwise known as Portlandite, and silicic acid $\left(\mathrm{H}_{4} \mathrm{SiO}_{4}\right)$ or $\mathrm{Si}\left(\mathrm{OH}_{4}\right)$, otherwise known as pozzolanic reaction, schematically represented as follows:

$\mathrm{Ca}(\mathrm{OH})_{2}+\mathrm{H}_{4} \mathrm{SiO}_{4} \rightarrow \mathrm{Ca}^{2+}+\mathrm{H}_{2} \mathrm{SiO}_{4}{ }^{2-}+2 \mathrm{H}_{2} \mathrm{O} \rightarrow$ $\mathrm{CaH}_{2} \mathrm{SiO}_{4} \cdot 2 \mathrm{H}_{2} \mathrm{O}$ (Balandis et al., 2006)

Three conditions must be met for ASR to occur: the reactive aggregate, high concentration of alkali in concrete pore solutions and humid environment of concrete (Berube et al., 2002). ASR occurs in concrete between silica present in the aggregate and alkali and hydroxide ions present in pore solutions forming liquid alkali silica gel. This gel absorbs water and may increase in volume and exert an expansive pressure inside the material. Usually concrete expansions are in direct proportion to alkali concentration (Berube et al., 2003).

The composition of ASR gel in exterior concrete structures may be different. The most common molar ratios of gel composite materials are $0.05-0.6\left(\mathrm{Na}_{2} \mathrm{O}+\mathrm{K}_{2} \mathrm{O}\right) / \mathrm{SiO}_{2}$ and $0-0.2(\mathrm{CaO}+\mathrm{MgO}) / \mathrm{SiO}_{2}$. The ratios may be different in places that are further from the reaction site, especially in reactions with calcium. T. Knudsen and N. Thaulow (1975) determined that in the majority of tested gels the molar ratio of $\mathrm{Na}_{2} \mathrm{O} / \mathrm{SiO}_{2}$ ranged between 0.2 and 0.5 and $\mathrm{CaO}$ content in ASR gels ranged between $0 \%$ and $20 \%$. Michael Thomas (2001) found that aggregate contained gel in 7-years-old concrete has a steady $\mathrm{Ca} / \mathrm{Si}$ ratio of approx. 0.25 and $\mathrm{K} /$ $\mathrm{Si}$ ratio between $0.1-0.3$. The bigger is the $\mathrm{Ca} / \mathrm{Si}$ ratio, the smaller is the $\mathrm{K} / \mathrm{Si}$ ratio.

The experimental test conducted by Hou et al. (2004) showed that the gel of alkali hydrosilicate (A-S-H), similar to the gel reaction product (ASR), is not formed when the paste of Portlandite or Portland cement containing calcium hydrosilicate with high calcium content and low silica content can react with silica. Under the said conditions, additional calcium hydrosilicate is formed in the reaction of $\mathrm{Ca}(\mathrm{OH})_{2}$ with melting silica, or gradual polymerization of calcium hydrosilicate. A-S-H, where polymerization prevails, is formed after the depletion of Portlandite and complete polymerization of calcium hydrosilicate. 
Basing on the aforementioned test results we may state that the formation of alkali hydrosilicates in the cement paste and concrete, involving the ordinary course of cement hydration reaction, increases the solution's $\mathrm{pH}$. $\mathrm{OH}^{-}$ ions react with reactive aggregate and consume the silica released in the reaction with $\mathrm{CH}$ and thus forming $\mathrm{C}-\mathrm{S}-\mathrm{H}$ until the entire $\mathrm{CH}$ present in the reaction zone is combined.

According to R. Dron and F. Brivot (1993), the gel of hydrosilicate formed during the reaction is scattered far away from aggregate micropores and the channels connecting them. The gel reacts with $\mathrm{Ca}^{2+}$ ions and expands causing the concrete to crack. However, it is not clear why the gel builds expansive pressure in the pores. Z. P. Bažant and A. Steffens (2000) raised a hypothesis that concrete cracking is caused by the expansive pressure concentrated at the boundaries of the aggregate and cement paste, where the expansive pressure displaces the gel into surrounding pores. When these pores are filled, the pressure is released through the cracks.

Analysing the structure of concrete many researchers, including G. M. Idorn (2001) and G. Goltermann (1995), have concluded that aggregate expansion by the pressure created inside the aggregate is not homogeneous. Such non-homogeneous expansion creates stress that is released by causing concrete to crack. Based on the analysis of crack patterns Japanese researchers Tsuneki Ichikawa and Masazumi Miura (2007) a modified mechanism of ASR, in which a reaction rim generated around the ASR-affected aggregate plays a significant role in the deterioration of concrete.

Their tests showed that alkali silicate cannot build the expansive pressure unless the aggregate is tightly pressed by the reaction rim. The reaction rim is slowly generated from the alkali silicate that covers the ASR affected aggregate. The consumption of alkali hydroxide by the ASR induces the dissolution of $\mathrm{Ca}^{2+}$ ions into the pore solution. The alkali silicate then reacts with $\mathrm{Ca}^{+}$ions to convert to an insoluble tight and rigid reaction rim. The reaction rim allows the penetration of alkaline solution but prevents the leakage of viscous alkali silicate, so that the alkali silicate generated afterward by the ASR is accumulated in the aggregate to give an expansive pressure enough for cracking the concrete. Very tiny aggregate such as fly ash may not cause the deterioration of concrete, since the ASR is completed before the formation of reaction rims.

\section{Experiment and active substance}

The aim of this paper is to determine the reactivity of aggregates obtained from the quarries in the Nemunas and the Neris river basins in Lithuanian territory on alkalisilica reaction and to propose active mineral admixtures to prevent the deterioration of concrete. Another objective is to propose and to test the methodology for the calculation of active mineral admixture content in order to neutralize Portlandite in the process of alkali - silica reaction of the aggregates.

For the experiment described in this paper fly ash from Poland was used as an active mineral additive that supresses alkali - silica reaction. Fly ash is one of the coal combustion products consisting of fine particles that are usually removed through the chimney with flue gas. According to the content of calcium oxide fly ash is divided into two groups: a group containing above $5 \% \mathrm{CaO}$ (F class) and a group containing $15-35 \% \mathrm{CaO}$ (C class). Fly ash with low $\mathrm{CaO}$ content mainly consists of silica dioxide and aluminium oxide in the form of aluminate glass with a certain amount of aluminium silicates and mullite crystals. Free $\mathrm{CaO}$ in class $\mathrm{F}$ fly ash reacts with alite $\left(\mathrm{C}_{3} \mathrm{~A}\right)$ and forms calcium hydraluminates. Such fly ash has binding properties (Skripkiūnas, 2007).

Shafaatian et al. studies the mechanism of fly ash action in reducing ASR effect. The experiments showed that fly ash reduces the amount of $\mathrm{OH}^{-}$ions in the solution, increases the strength of concrete specimens (Yositake et al., 2013), (Shafaatian et al., 2012) and reduces the dissolution of aggregates containing silica dioxide (Shafaatian et al., 2012).

Usually, the expansion caused by ASR can be controlled by replacing $25 \%$ of the cement with fly ash. Thomas et al. (2010) found that in cases where $25 \%$ and $40 \%$ of Portland cement were replaced by fly ash concrete selling and cracking significantly reduced in all mixtures with different reactive aggregates.

Although mixtures with $40 \%$ of fly ash were tested (Thomas et al., 2010), only up to $30 \%$ of Portland cement by weight can be replaced by fly ash of class $F$ because higher content of fly ash in the cement paste may have a negative effect on concrete strength (Gengying Li, 2006). Such a situation limits the use of fly ash. Gengying Li (2006) proposes to mix nano- $\mathrm{SiO}_{2}$ into fly ash. A small amount of nano- $\mathrm{SiO}_{2}$ added to fly ash increases its pozzolanic activity and speeds up the pozzolanic reaction and thus improves concrete strength. The tests showed that nano- $\mathrm{SiO}_{2}$ increases not only early but also later-age strength of concrete.

In general, concrete with fly ash has a longer setting time and this is the reason for lower early-age strength compared to the strength after the same curing time in concrete with Portland cement (Olba, 2008). Yoshitake et al. (2013), however, reported higher later-age strength of such concretes. It should be noted that the Young modulus in concrete with fly ash is 1.2 times higher than in concrete without this admixture.

Esteves et al. (2012) also investigated the using of bio -mass fly ash as a pozzolanic admixture. Although this type of ash is categorized as Class $\mathrm{C}$, it was found to have a positive effect of reducing the expansion caused by ASR.

\section{Bonding agent}

Cement as the main bonding agent was replaced by fly ash in the experiment. The selection of cement type is as much important as the type of aggregate because silica oxide and silica acid present in the aggregate react with alkali and oxides present in the cement.

Since water-soluble sodium and potassium oxides $\left(\mathrm{Na}_{2} \mathrm{O}\right.$ and $\left.\mathrm{K}_{2} \mathrm{O}\right)$ present in the cement combine with $\mathrm{OH}^{-}$ ions and participate in ASR reaction (ASTM C 1293), therefore the total alkali content calculated as $\mathrm{Na}_{2} \mathrm{O}_{\text {ekv }}$ may not exceed $0.8 \%$.

Since the effect of mineral admixture was investigated, it was important to have the Portland free of any impurities. To this end Portland cement of Class CEM I 42.5 N produced 
by AB "Akmenès cementas", i.e. pure Portland cement with the compressive strength of $42.5 \mathrm{MPa}$ with normal hardening rate was used in the experiment. Composition off the cement: $63,13 \% \mathrm{CaO} ; 20,48 \% \mathrm{SiO}_{2} ; 5,55 \% \mathrm{Al}_{2} \mathrm{O}_{3} ; 3,58 \%$ $\mathrm{Fe}_{2} \mathrm{O}_{3} ; 0,73 \% \mathrm{SO}_{3} ; 3,99 \% \mathrm{MgO}$. Mineral composition of the clinker is presented in table 1 .

Table 1. Composition of clinker

\begin{tabular}{|c|c|c|c|}
\hline $\mathrm{C}_{3} \mathrm{~S}, \%$ & $\mathrm{C}_{2} \mathrm{~S}, \%$ & $\mathrm{C}_{3} \mathrm{~A}, \%$ & $\mathrm{C}_{4} \mathrm{AF}, \%$ \\
\hline 56,60 & 15,76 & 8,59 & 10,85 \\
\hline
\end{tabular}

Fly ash from Poland was used as an active admixture of the composition presented in table 2 .

Table 2. Composition of fly ash

\begin{tabular}{|c|c|}
\hline Substance & Test result (wt \%) \\
\hline Loss on ignition & 5,74 \\
\hline $\mathrm{SO}_{3}$ & 2,15 \\
\hline Chlorides $\left(\mathrm{Cl}^{-}\right)$ & $<0,01$ \\
\hline Free $\mathrm{CaO}$ & 0,01 \\
\hline Total $\mathrm{CaO}$ & 2,44 \\
\hline Active $\mathrm{SiO}_{2}$ & 37,33 \\
\hline $\mathrm{SiO}_{2}$ & 48,79 \\
\hline $\mathrm{Al}_{2} \mathrm{O}_{3}$ & 25,24 \\
\hline $\mathrm{Fe}_{2} \mathrm{O}_{3}$ & 5,30 \\
\hline $\mathrm{SiO}_{2}+\mathrm{Al}_{2} \mathrm{O}_{3}+\mathrm{Fe}_{2} \mathrm{O}_{3}$ & 79,33 \\
\hline $\mathrm{MgO} \mathrm{O}$ & 2,37 \\
\hline Soluble phosphates like $\mathrm{P}_{2} \mathrm{O}_{5}$ & $0,00222(22 \pm 1 \mathrm{mg} / \mathrm{kg})$ \\
\hline $\mathrm{Na}_{2} \mathrm{O}$ & 0,86 \\
\hline $\mathrm{K}_{2} \mathrm{O}$ & 3,56 \\
\hline $\mathrm{Na}_{2} \mathrm{O}_{\text {ekv. }}$ & 3,20 \\
\hline
\end{tabular}

\section{Aggregates}

Alkali present in the cement and water react with $\mathrm{SiO}_{2}$ present in the aggregate. Rocks, such as opal, chalcedony, chert, flint and similar types of rock with a large amount of amorphous $\mathrm{SiO}_{2}$, mixed with sand and gravel grains most often cause the adverse reaction. Therefore quarries uncontaminated with the said rocks are of great value (Hou et al., 2004).

For the variety of results, quarries of different contamination by such reactive particles were selected. The following quarries of the Neris and the Nemunas river basins in Kaunas region were selected:

- Kvesai quarry (the Nemunas river basin);

- Rizgonys quarry (the Neris river basin);

- Zatyšiai quarry (the Neris river basin)

Historically, the quarries of the Nemunas river basin are polluted with flint rock, therefore the Kvesai quarry is taken as polluted with reactive rock, whereas Rizgonys and Zatyšiai quarries of the Neris basin are much cleaner, although in practice all Lithuanian quarries are more or less polluted with reactive rocks. Thus, the biggest expansion is the most likely in specimens made with the aggregate from Kvesai quarry, although the layers in every quarry are different and the final result might not be as predicted.
Two aggregate sizes were used for the experiment: coarse aggregate of $4 / 8$ fraction and fine aggregate of $0 / 4$ fraction.

Concrete mix, where alkali - silica reaction was most likely to occur, was used in the experiment as the control mix. A particularly reactive aggregate - chert of $4 / 8$ fraction - was selected as the course aggregate in this mix.

A qualitative X-ray analysis of the aggregates was done. $\mathrm{X}$-ray diffraction curves of the specimens were obtained by diffractometer DRON 6 (Bourevestnik Inc., Russia) using monochromatized $\mathrm{Cu} \mathrm{K} \alpha$ radiation (Ni filter, step width of $0,02^{\circ}$, counting time per step $0,5 \mathrm{~s}$, plate voltage $U a=30 \mathrm{kV}$, current $I=20 \mathrm{~mA}$ ).

The test results showed (Fig. 1-3) that all aggregates contained limestone $\left(\mathrm{CaCO}_{3}\right)$ several varieties of $\mathrm{SiO}_{2}$ and other minerals that do not participate in alkali - silicate reaction. The X-ray image of carbonate chert (Fig. 3) distinguished of all other images: the mountain-shape concentration of peaks shows that the aggregate contains amorphous $\mathrm{SiO}_{2}$, which reacts with the alkali and causes degradation. Aggregates from the quarries were cleaner; the X-ray of the aggregate from Kvesai quarry shows only small "peak mountains" between peaks that indicate the possible presence of amorphous $\mathrm{SiO}_{2}$

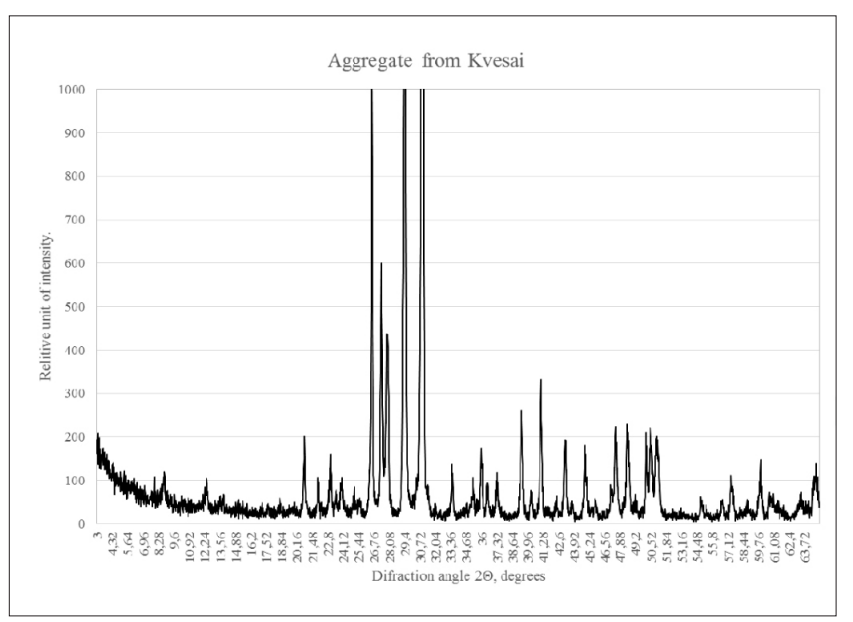

Fig. 1. $\mathrm{A}-\mathrm{CaCO}_{3} ; \mathrm{B}-\mathrm{SiO}_{2}$ (quartz); $\mathrm{C}-\mathrm{CaMg}\left(\mathrm{CO}_{3}\right)_{2} ; \mathrm{D}-\mathrm{Na}$ $\mathrm{Al} \mathrm{Si}_{3} \mathrm{O}_{8}$

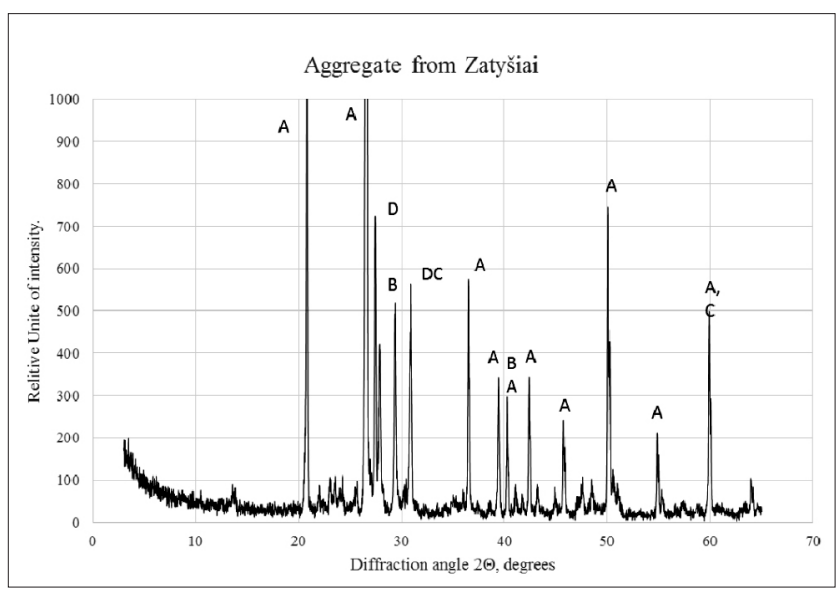

Fig. 2. $\mathrm{A} \mathrm{SiO}_{2}$ (silica); $\mathrm{B}-\mathrm{CaCO}_{3} ; \mathrm{C}-\mathrm{CaMg}\left(\mathrm{CO}_{3}\right)_{2} ; \mathrm{D}-(\mathrm{Na}$, $\mathrm{Ka})\left(\mathrm{Si}_{3} \mathrm{Al}\right) \mathrm{O}_{8}$ 


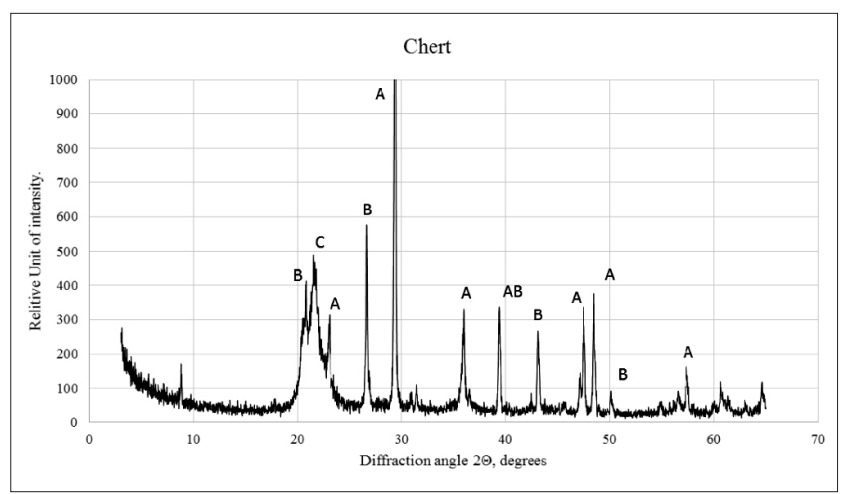

Fig. 3. $\mathrm{A}-\mathrm{CaCO}_{3} ; \mathrm{B}-\mathrm{SiO}_{2}$ (silica); $\mathrm{C}-\mathrm{SiO}_{2}$ (cristobalite)

\section{Methodology for the neutralization of alkali-driven concrete degradation}

Perennial and comprehensive studies of alkali - silica reaction enable to presume that 3 components are present in the process: amorphous $\mathrm{SiO}_{2}$ (chert and flint), sodium and potassium hydroxide and calcium hydroxide. These components react in two stages (Gumuliauskas, Navickas 1992):

- at first sodium and potassium hydroxides react with amorphous $\mathrm{SiO}_{2}$ forming alkaline hydrosilicate (water glass) that does not have any adverse effect on concrete, if only staining;

- in the second step the alkaline hydrosilicate reacts with calcium hydroxide $\mathrm{Ca}(\mathrm{OH})_{2}$ (portlandite) that is produced after alite $3 \mathrm{CaO} \cdot \mathrm{SiO}_{2}$, and later belite $\mathrm{CaO} \cdot \mathrm{SiO}_{2}$, bind with water forming insoluble colloidal substance that builds a semipermeable membrane around the reactive particle of the aggregate. This membrane enables only unidirectional movement of materials accompanied by high osmotic pressure.

The only way to prevent the adverse effect of the interaction of reactive aggregates with the alkali of cement clinker is to prevent the reaction of alkali and aggregate reaction products with cement clinker mineral hydrolysis product $\mathrm{Ca}(\mathrm{OH})_{2}$, i.e. the cement must contain very fine pozzolanic admixtures, such as tripoli or crushed chert (at least $20 \%$ of clinker weight) that would immediately react forming calcium silicates (Gumuliauskas, Navickas 1993); such reactive $\mathrm{SiO}_{2}$ may be find in ground blast furnace slag, fly ash or $\mathrm{SiO}_{2}$ micro-particles.

In the binding process of concrete, at first portlandite $\mathrm{Ca}(\mathrm{OH})_{2}$ is formed from alite $\left(3 \mathrm{CaO} \cdot \mathrm{SiO}_{2}\right)$, the content of which in the clinker ranges between $45-60 \%(50 \%$ in average), and later from belite $\left(2 \mathrm{CaO} \cdot \mathrm{SiO}_{2}\right)$, the content of which ranges between $20-30 \%$ :

$2\left(3 \mathrm{CaO} \cdot \mathrm{SiO}_{2}\right)+6 \mathrm{H}_{2} \mathrm{O}=3 \mathrm{CaO} \cdot 2 \mathrm{SiO}_{2} \cdot 3 \mathrm{H}_{2} \mathrm{O}+$ $3 \mathrm{Ca}(\mathrm{OH})_{2}$,

$2\left(2 \mathrm{CaO} \cdot \mathrm{SiO}_{2}\right)+4 \mathrm{H}_{2} \mathrm{O}=3 \mathrm{CaO} \cdot 2 \mathrm{SiO}_{2} \cdot 3 \mathrm{H}_{2} \mathrm{O}+$ $\mathrm{Ca}(\mathrm{OH})_{2}$.

During concrete settling, while the surface of concrete is moisturized, cement hydration degree reaches $0,5-0,6$. Reactive pozzolanic admixtures, i.e. reactive $\mathrm{SiO}_{2}$, bind the released portlandite into hydrosilicates of higher or lower basicity:
$\mathrm{Ca}(\mathrm{OH})_{2}+\mathrm{SiO}_{2}=\mathrm{CaO} \cdot \mathrm{SiO}_{2} \cdot \mathrm{H}_{2} \mathrm{O}$

For this reaction to occur the content of reactive $\left[\mathrm{SiO}_{2}\right]^{\text {act }}$ must be

$$
\left[\mathrm{SiO}_{2}\right]^{\mathrm{akt}}=60 / 74 \mathrm{Ca}(\mathrm{OH})_{2}=0.81 \mathrm{Ca}(\mathrm{OH})_{2}
$$

The amount of portlandite $\mathrm{Ca}(\mathrm{OH})_{2}$ in concrete formed from alite, which accounts for $1 / 2$ of clinker cement (C) weight, is:

$$
\begin{aligned}
& \mathrm{Ca}(\mathrm{OH})_{2}=0.5 \cdot \frac{3 \mathrm{Ca}(\mathrm{OH})_{2}}{3 \mathrm{CaO} \cdot 2 \mathrm{SiO}_{2} \cdot 3 \mathrm{H}_{2} \mathrm{O}} \cdot \mathrm{C}= \\
& =0.5 \cdot 0.65 \cdot \mathrm{C}=0.32 \cdot \mathrm{C}
\end{aligned}
$$

It is recommended to bind approximately $0,5-0,7(0,6$ in average) content of portlandite with reactive pozzolans to avoid the consequences if of alkali reaction with reactive aggregates, i.e. volume deformations. Therefore the content of $\left[\mathrm{SiO}_{2}\right]^{\text {act }}$ should be:

$$
\left[\mathrm{SiO}_{2}\right]^{\mathrm{act}}=0.81 \cdot 0.6 \cdot 0.32 \cdot \mathrm{C}=0.16 \cdot \mathrm{C} .
$$

The percentage concentration $(\mathrm{X})$ of $\left[\mathrm{SiO}_{2}\right]^{\text {act }}$ in pozzolanic admixtures must be known:

$$
\mathrm{P}=\frac{\left[\mathrm{SiO}_{2}\right]^{\text {act }}}{\frac{x}{100}}=\frac{0.16}{\frac{x}{100}} \cdot \mathrm{C} .
$$

The content of pozzolanic admixtures in relation to the base quantity of the cement $C_{\mathrm{b}}$ to produce the concrete of required strength is calculated from the equation:

$$
\mathrm{P}_{\mathrm{Cb}}=\mathrm{C}_{b}-\mathrm{C}=\frac{0.16 \cdot \mathrm{C}_{b}}{\frac{x}{100}+0.16} \text {. }
$$

Using the data of fly ash given in Table 2 in Equation 5 , we calculate that $25,8 \mathrm{wt} \%$ of fly ash must be added to neutralize the Alkali - silica reaction of concrete.

\section{Results}

The specimens were measured after 3,6 and 9 months following the beginning of the experiment. After the measuring the volumetric strains were calculated. The effect of fly ash used as the mineral admixture was determined by analysing the relation between the average volumetric strain and the content of fly ash in concrete mix in the batch of specimens with the same content of the fly ash.

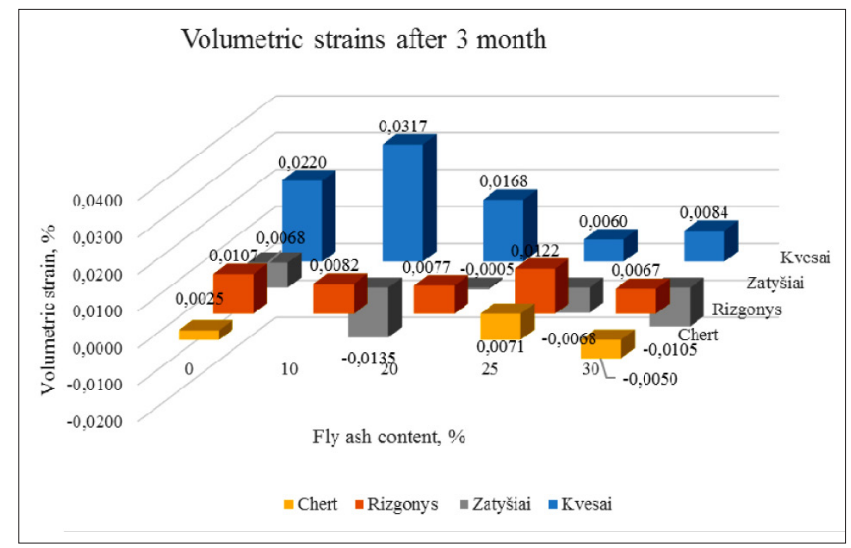

Fig. 4. Average volumetric strains of specimens after 3 months 
Measuring results obtained 3 month after the beginning of the experiment (Fig. 4) showed that in general the biggest deformations and expansion of the volume of specimens was observed in specimens with the aggregate from Kvesai quarry. The volumetric strain in specimens made of concrete mix with aggregate from this quarry and $0 \%$ of fly ash was 0,0220 , i.e. several times higher compared to specimens of the same composition with aggregates from Rizgonys and Zatyšiai quarries. In some cases even contraction of the prism volume was observed in specimens with aggregates from the latter quarries. The volume decreases due to concrete contraction during curing. The volumetric strains in all specimens after 3 months of curing were very low and the change in size did not depend on the fly ash content in the mix. This implies that after 3 months of curing in sodium hydroxide solution of $+20{ }^{\circ} \mathrm{C}$, the alkali - silica reaction did not occur due to low temperature of the solution and/or because the specimens were not saturated with $\mathrm{Na}^{+}$ ions that did not increase the total alkali content in the mix.

After 6 months of soaking in $\mathrm{NaOH}$ solution much higher deformations of specimens were observed (Fig. 5). From Figure 5 we may see that, similar to the results obtained after 3 months of curing, the biggest volumetric strains were observed in specimens with aggregates from Kvesai quarry. The only difference was that the strains were more regular. This is evidenced by the resulting functional relationship between the deformations and fly ash content. The analysis of obtained data showed that the empirical coefficient of fly ash content and the average volumetric strains in specimens with aggregates from Kvesai quarry was 0.9005 , and the correlation coefficient was 0.9489 .

It should be also noted that already after 6 months of curing the volumetric strains in specimens with the aggregate from Kvesai quarry $(0,0395 \%)$ have almost reached the limit of $0,04 \%$. This limit is established by the Canadian Standards Association (CSA) (Shehata, Thomas 2002). Volumetric strains are several times lower in specimens with the same aggregate but higher content of fly ash $(25 \%$, $30 \%$ ); therefore it is clear that mineral admixture, active fly ash is our case, has a positive effect. Such a reaction in specimens with aggregate from this quarry could have been influenced by several factors. Firstly, the limestone $\mathrm{CaCO}_{3}$ present in the aggregate could have been bound by non-crystalline and/or microcrystalline $\mathrm{SiO}_{2}$, and thus the quartz present in the aggregate could have been deformed and cause the alkali - silica reaction.

According to the obtained results we may see that alkali - silica reaction is the strongest in these specimens. Most probably it is because of the presence of more reactive rocks than in the aggregates from Rizgonys or Zatyšiai quarries.

Alkali - silica reaction processes in specimens with aggregates from Zatyšiai quarries are weaker. Volumetric strains in these specimens are much lower and less dependent on the content of mineral admixture. As seen from the X-ray images, the aggregate from this quarry mostly contains $\mathrm{SiO}_{2}$ with crystalline matrix.
The volumetric strains after 6 months of curing are the lowest in specimens containing the aggregate from Rizgonys quarry. They do not depend on the content of fly ash either. No alkali - silica reaction was observed in these specimens after 6 months of curing (Fig. 5).

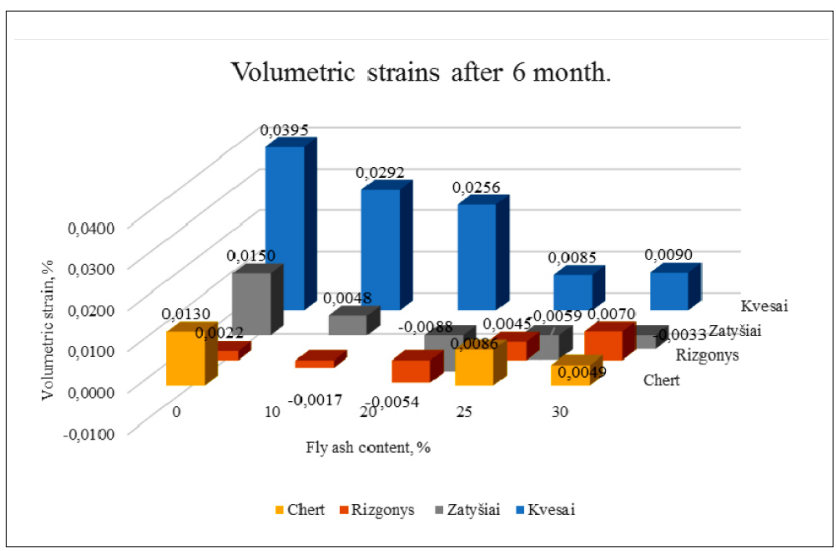

Fig. 5. Average deformations after 6 months

Volumetric strains observed after 6 months in specimens with chert aggregate are not significant compared to specimens with the aggregate from Kvesai quarry (Fig. 5); however a strong relationship between the volumetric strain and the content of fly ash is observed. In these specimens Alkali - silica reaction (Fig. 6) is much more prominent compared to specimens made of other concrete mixes. Figure 6 illustrates a pressed out granule of the aggregate, an indication of Alkali - silica reaction. Such behaviour was observed in the majority of specimens with reactive chert aggregate. Along with the pressed out granules we may see a cracking pattern (Fig. 7).

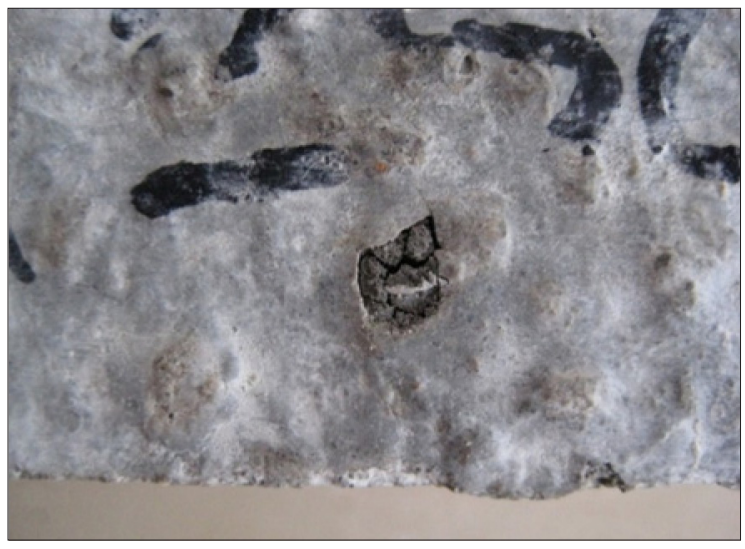

Fig. 6. A granule of aggregate pressed outside the specimen surface

Visual changes were observed even in specimens with $25 \%$ of fly ash; however no apparent changes were seen in specimens with $30 \%$ of fly ash. Therefore, we may state that $30 \%$ of mineral admixture (fly ash) is enough to prevent the Alkali - silica reaction even in a very aggressive environment, which in our case was $1 \mathrm{~N} \mathrm{NaOH}$ solution of $20{ }^{\circ} \mathrm{C}$, when the aggregate is reactive chert. 


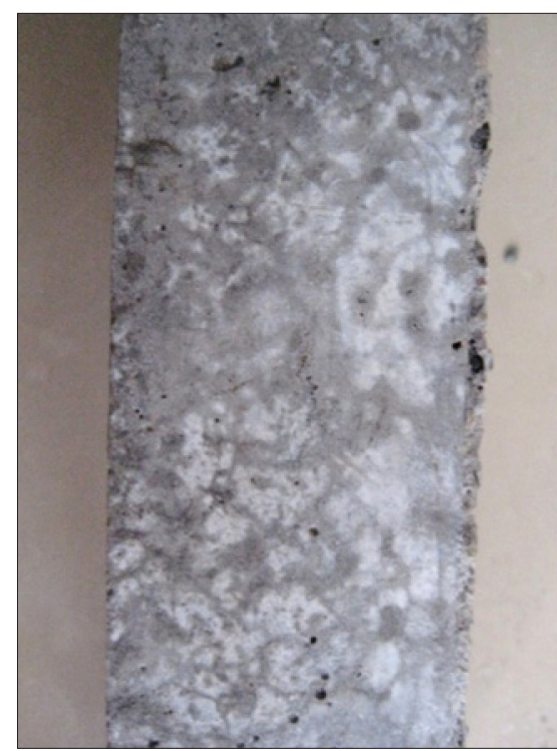

Fig. 7. A visible cracking pattern in the specimen with rocks after 6 months in alkaline environment

Generally, the alkali - silica reaction was the most significant in the specimens with chert aggregate after 6-9 months (Fig. 8). The deformation of these specimens was the most prominent in the said curing period. Figures 8 and 9 illustrate that $30 \%$ of fly ash is sufficient to prevent the Alkali - silica reaction even when a very aggressive aggregate is used.

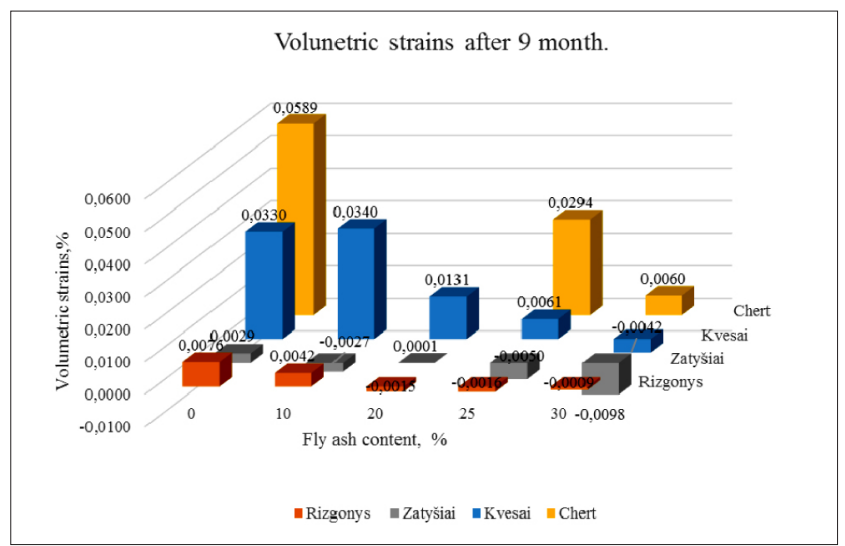

Fig. 8. Average volumetric strains in specimens after 9 months

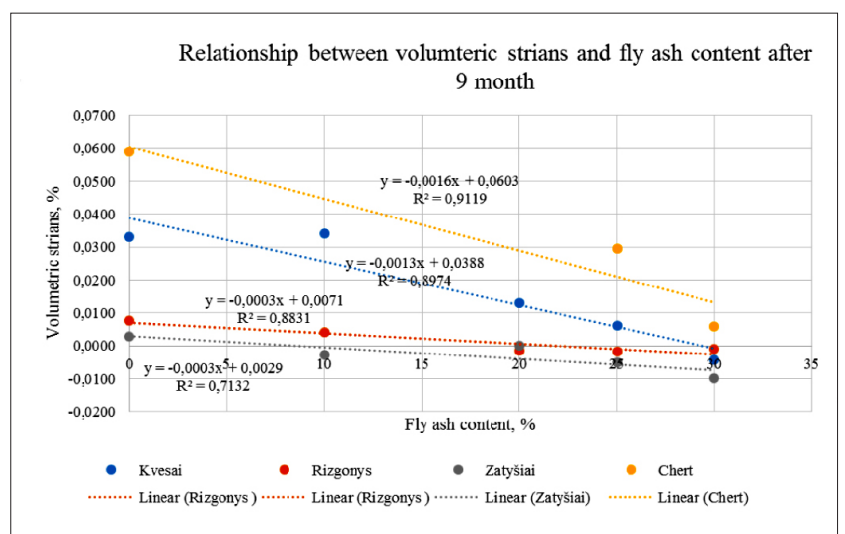

Fig. 9. Relationship between volumetric strains and fly ash content
Using the volumetric strain measurement results at 9 months and in view of different fly ash content, reliable firstdegree equations were developed (Fig. 9), where correlation coefficients, subject to the type of aggregate, change in the interval $0,71 \ldots 0,91$.

The effect of alkali - silica reaction was visually seen in the last stage of the experiment. Almost all specimens, where chert was used as the coarse aggregate and cement was replaced by $25 \%$ and $0 \%$ of fly ash, have cracked, granules of the aggregate were pressed out from the surface, various swellings, which were not seen before, were observed on the sides of the prisms (Fig. 10).

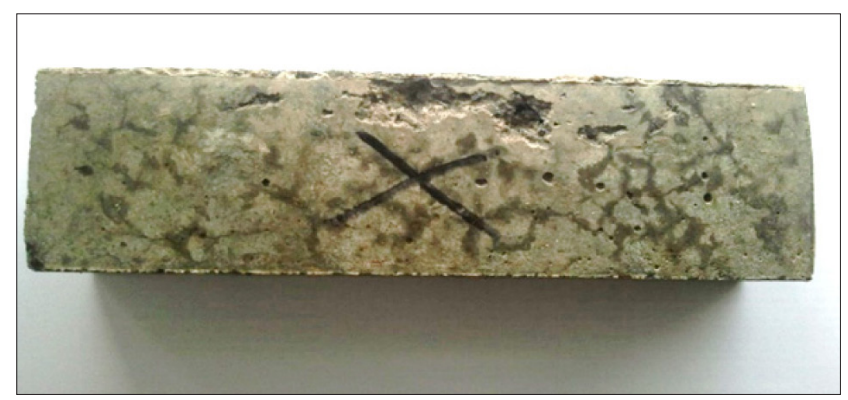

Fig. 10. A specimen after 9 months curing in aggressive environment

It should be also noted, that visual symptoms of expansion were also observed in specimens containing the aggregate from Kvesai quarry and $0 \%$ of fly ash. Specimens of this batch also bore a slight cracking pattern. These specimens demonstrated the biggest volumetric strains after 3 and 6 months.

\section{Discussion}

Cracking of concrete structure, due to ASR, is caused by the expansion of calcium hydrosilicate gel - a product of a chemical reaction (ASR) between the reactive silica contained in the aggregates and the alkalis within the cement paste. Active mineral admixtures, such as pozzolans, chert, silica-fume, fly ash, slag etc. help to mitigate the negative effect of ASR. The aim of using the said mineral admixtures is to bind the alkalis within the cement paste before the final setting of concrete and to prevent the degradation resulting from the expansion of silica gel.

ASR is actively investigated and mitigation methods to prevent ASR are being developed. Researchers and engineers working in this field face numerous difficulties. They try to find the most optimal and universal method to prevent the alkali - silica reaction. Another important issue is to find out how the gel, being a liquid substance, can damage such a solid material as concrete. A number of hypotheses have been suggested by the researchers; however the phenomenon has not been fully investigated.

In cases when very reactive aggregates are used, 50\% of cement have to be replaced by fly-ash or slag to control the ASR. Unfortunately, such a high content of pozzolanic admixtures has a negative effect on concrete strength. Adding of several types of admixtures, for instance fly ash with silica-fume, help to avoid the negative outcomes. The 
proven synergic effect of the said substances enables to reduce the content of the admixtures used in the cement mix.

The studies of ASR are very important. The negative effect of ASR can manifest in spite of preventive measures. For this reason further investigations in this field are necessary because there are still many unanswered questions. Answers must be found in order to successfully mitigate the damage of ASR.

\section{Conclusions}

Specimens where examined every 3 month and further findings where observed. No significant symptoms of ASR were noticed in the first three months of the experiment. After 6 months the following ASR indications were observed:

- Expansions of the tested prisms;

- visually apparent cracking pattern on the specimen surface;

- Pressed out granules of the aggregate on the specimen surface.

After 9 months of the experiment the ASR indications were more apparent. The available data suggest the process of alkali - silica reaction in the specimens.

The relationship between the average volumetric strain and the fly ash content became apparent after 6 , while at three months since the beginning of the experiment such relationship was not present. The analysis of experimental data shows that deformations are less significant in specimens with a higher content of fly ash used as an active mineral admixture. The same trend was observed in specimens of all types of concrete mix, except for the specimens with the aggregate from Rizgonys quarry after 6 months in aggressive environment. After 9 months, however, minor but typical deformations were also seen in specimens with the said aggregate.

Indications of alkali - silica reaction were especially noticeable in specimens with the aggregate from Kvesai quarry, where the most significant deformations in prisms with $0 \%$ fly ash reached $0,0395 \%$. The deformations had the highest functional dependency on the fly ash content in the mix, the correlation coefficient $r=0,9489$.

Indication of alkali - silica reaction, namely pressed out granules of the aggregate and cracking pattern was also observed after 6 months in specimens with very reactive aggregate (chert). These specimens demonstrated big deformations at 9 months since the beginning of the experiment. According to all criteria, the strongest manifestation of alkali - silica reaction was observed in specimens with carbonate chert. $30 \%$ of fly ash in concrete mix was enough to stop the Alkali - silica reaction.

\section{References}

Standard Test Method for Determination of Length Change of Concrete Due to Alkali-Silica Reaction ASTM C 1293.

Balandis, A. et al. 2006 . Statybinių medžiagų chemija II dalis : mokomoji knyga, Kaunas: Technologija 85 p. ISBN 995509-728-0

Bažant, Z. P.; Steffens A. 2000. Mathematical model for kinetics of alkali-silica reaction in concrete, Cement \& Concrete. Research. 30 (3): 419-428 doi: 10.1016/S00088846(99)00270-7.
Bérubé, M. A.; et al. 2002 M. Labaratory assessment of alkali contribution by aggregates to concrete and application to concrete structures affected by alkali - silica reactivit,. Cement and Concrete research: 32 (8): p. 1215-1227 doi:10.1016/S0008-8846(02)00766-4.

Bleszynski, R., et al. 2002. Durability of ternary blend concrete with silica fume and blast-furnace slag: laboratory and outdoor exposure site studines. ACI Materials Journal 99 (5): p. 499-508.

Boddy, A. M et al. 2003. The effect of silica content of silica fume on its ability to control alkali - silica reaction, Cement and Concrete research 33 (8): p. 1263-1268 doi: 10.1016/S00088846(03)00058-9.

Dron, R.; Brivot, F. 1993. Thermodynamic and kinetic approach to the alkalisilica reaction. Part 2: Experiment. Cemement \&. Concrete. Research. 23 (1): 93-103 doi: 10.1016/0008-8846(93)90139-Z.

Feng, X. et al. 2005. Studies on lithium salts to mitigate ASRinduced expansion in new concrete: a critical review, Cemenent and concrete research 35 (9): p. 1798-1798 doi: 10.1016/j.cemconres.2004.10.013.

Goltermann, P. 1995. Mechanical prediction of concrete deterioration-part 2: classification of crack patterns, ACI Mater. Journal. 92 (1) 1-6.

Gumuliauskas A., Navickas A. A. Reaktingujų užpildų panaudojimo betonuose ir skiediniuose ypatumai. Statybinès medžiagos. Respublikinès mokslinės-techninès konferencijos medžiaga. Kaunas-Vilnius, 1992.

Gumuliauskas, A., Navickas A. A., Betono užpildu iš Lietuvos žvyrynu užterštumas reaktingomis priemaišomis. Respublikinés mokslinès-techninès konferencijos medžiaga. Kaunas: KTU, 1993.

Gumuliauskas, A. et al. 2007. Grūdètu statybiniu kompozitų destrukcija. Kaunas: Technologija, 95 p. ISBN 978-9955686-34-7.

Hou, X. et al. 2004. Fromation of ASR gel and the roles of C-S-H and portlandite. Cement and Concrete research 34 (9): p. 1683-1696 doi: 10.1016/j.cemconres.2004.03.026.

Ichikawa, T. et al. 2007 . Modified model of alkali-silica reaction, Cement and Concrete research 37 (9): p. 1291-1297 doi: 10.1016/j.cemconres.2007.06.008.

Idorn, G. M. 2001. A discussion of the paper "Mathematical model for kinetics of alkali-silica reaction in concrete" by Zdeněk P. Bažant and Alexander Steffens, Cemement \&. Concrete. Research. 31 (7): p. 1109-1110, doi: 10.1016/S0008-8846(01)00522-1.

Yositake, I. et al. 2013. Uniaxial tensile strenth and tensile Youong's modulud of fly ash concrete, Constructio and building materials 40: p. $514-521$ doi: $10.1016 / j$. conbuildmat.2012.11.022.

Knudsen, T. et al. 1975. Quantitative microanalyses of alkalisilica gel in concrete. Cement and Concrete Research 5 (5) 443- 454 doi: 10.1016/0008-8846(75)90019-8.

Li, G. 2006. Properties of high - volume fly ash concrete incorporating nano $-\mathrm{SiO}_{2}$, Cement and Concrete research 34 (6): p. 1043-1049 doi: 10.1016/j.cemconres.2003.11.013.

Lingård, J. et al. 2011 . Alkali-silica reactions (ASR): Literature review on parametres influencing laboratory perfomance testing, Cement and Concrete research 42 (2): p. 223-243 doi: 10.1016/j.cemconres.2011.10.004.

LST 1974:2012

Olba, K. H. 2008. Specifying fly ash for use in concrete. Silver Spring: NRMCA, http://www.nrmca.org/research/cif\%20 spring $\% 2008 \% 20$ fly $\% 20$ ash.pdf $>$ 


\section{RILEM TC 191-ARP}

Shafaatian, S. M. H et al. 2013. How does fly ash mitigate alkalisilica reaction (ASR) in accelerated mortar bar test?, Cement \& Concrete research 37: p. 143-153 doi: 10.1016/j.cemconcomp.2012.11.004

Shehata, M. H., Thomas. M. D. A., 2002. Use of ternary blends containing silica fume and fly ash to suppress expansion due to alkali-silica reaction in concrete, Cement and Concrete Research Volume 32, Issue 3, March 2002, Pages 341-349. doi: 10.1016/S0008-8846(01)00680-9

Skripkiūnas, G. 2007. Statybinių konglomeratų struktūra ir savybės. Kaunas: Technologija: 334 p. ISBN 978-9955-686-50-7.
Thomas, M. D. et al. 2010. Effect of fly ash on the expantion of concrete due to alkali - silica reaction - exposure site studines, Cement and Concrete composites 33 (3): p. 359367 doi: 10.1016/j.cemconcomp.2010.11.006

Turanli, L. et al. 2003. Use of ground clay brick as puzzolanic material to reduce the alkali-silica reaction, Cement and Concrete Research 33 (10) 1539-1542 doi: 10.1016/S00088846(03)00101-7.

Vektatris, B.; Vilkas, V. 2006. Betono tvarumas. Betono sulfatinė ir šarminè korozija, atsparumas šalčiui ir karbonizacijai. Tyrimai ir prevencinès priemonès [monografija]. Kaunas: Technologija, Prieiga per internetą: < www. balkonurenovacija.lt/betono_korozija.pdf>.

Audrius GRINYS - Doctor of Technology Sciences, Assoc. Professor of the Department of Building Materials at Kaunas University of Technology.

Main research area: ready mix and precast concrete technology, chemical additive of concrete, concrete deformability, concrete strength and utilization of waste materials.

Address: Studentu g. 48, LT-51367 Kaunas, Lithuania.

Tel.: $\quad+37065690441$

E-mail: audrius.grinys@ktu.lt

Vytautas BOCULLO - Master graduated degree of the Department of Building Materials at Kaunas University of Technology.

Main research area: Concrete ASR.

Address: Studentu g. 48, LT-51367 Kaunas, Lithuania.

Tel.: $\quad+37068248654$

E-mail: donbocullo@gmail.com

\footnotetext{
Algirdas GUMULIAUSKAS - Department of Building Materials at Kaunas University of Technology.

Main research area: Concrete ASR.

Address: Studentu g. 48, LT-51367 Kaunas, Lithuania.

Tel.: $\quad+37061651042$

E-mail: agum@takas.lt
} 